\title{
In-Vivo Study of Boswellia serrata for Modulating Immune System and Quenching Free Radicals
}

\author{
Kavita Chahal $^{1, *}$, Megha Jha ${ }^{2}$ \\ ${ }^{1}$ Department of Botany, Government College Bichhua, Chhindwara, Madhya Pradesh, India \\ ${ }^{2}$ Department of Biotechnology, R\&D, Pinnacle Biomedical Research Institute, Bhopal (M.P), India
}

Received April 16, 2020; Revised May 13, 2020; Accepted June 16, 2020

Copyright $\mathrm{C} 2020$ by authors, all rights reserved. Authors agree that this article remains permanently open access under the terms of the Creative Commons Attribution License 4.0 International License

\begin{abstract}
In several diseased conditions like asthma, allergy, ageing, arthritis, cancer etc., there is a production of reactive nitrogen and oxygen species, as well as our immune system also gets harmed. In order to stop or quench these harmful free radicals, antioxidants, which are the first line of defense, are used. And the immune system can be modulated to work properly by using natural agents like medicinal plants, having antioxidant property. In this context, the present study was undertaken to investigate the immunomodulatory activity and free radical quenching ability of the Boswellia serrata Roxb. (Bs) in murine model. This herb is known to afford protection to human physiological system against diverse stressors. It was tested at three dose levels of $50 \mathrm{mg} / \mathrm{kg}$ of mice body weight, $100 \mathrm{mg} / \mathrm{kg}$ of mice body weight, and $150 \mathrm{mg} / \mathrm{kg}$ of mice body weight for five consecutive days. Alpha tocopherol $(25 \mathrm{mg} / \mathrm{kg}$, of mice body weight) and Di-methyl Sulphoxide (35mg $/ \mathrm{kg}$ of mice body weight) were used as the reference standards. The extent of protection against immunosuppression was evaluated after 9 days of respective drug administration, by measuring macrophage phagocytic activity. A statistically significant antioxidant and immunomodulatory activity were shown by the extract of Boswellia serrata as evident by its effect on the activity of non-enzyme antioxidant reduced glutathione (GSH), antioxidant enzyme glutathione peroxidase (GPx), the degree of lipid peroxidation, and increase in the number of peritoneal macrophages.
\end{abstract}

Keywords Boswellia serrata, Antioxidant, Immunomodulatory, Glutathione Peroxidase, Lipid Peroxidation, Peritoneal Macrophages

\section{Introduction}

In case of chronic inflammatory conditions, the immune system sometimes go out of the track and harm the host himself. Therefore, the modulation of immune responses becomes necessary. The immunological responsiveness of an organism can be increased by agents that can modulate the immune system by interfering with its regulatory mechanisms in a process called as immunomodulation [1-3]. Chronic inflammatory conditions also produce free radicals, which are unstable molecules, as a byproduct. In excessive amounts these free radicals are harmful for healthy tissues [4-6]. These radicals can be better scavenged by antioxidation, which a mechanism of stopping or quenching harmful free radicals. Hence, for treating an inflammatory condition immunomodulation can go hand in hand with antioxidant activity [7-9].

There is an increasing concern about use of synthetic immunomodulating agents and antioxidants which has increased researcher's interest in finding out alternatives from natural sources [10-12]. As mentioned in Charaka Samhita [13], popularity of natural healthcare, side effects of synthetic drugs, better cultural acceptability, better compatibility with the human body and increased efficiency of plant derived drugs, prohibitive cost of allopathic drugs, and unavailability of allopathic drugs in remote areas, and a growing interest in preventing future health problems and a view to address specific health concerns, are the main reasons for the deviation of people towards plant-based medicines [14-16].

Boswellia serrata Roxb. belongs to Burseraceae family and commonly known as Salai, Frankincense, Gajabhakshya, Sallaki Guggul. Boswellia serrata Roxb., is a large branching tree found in India, the Middle East \&Northern Africa. The bark contains a gummy oleo-resin [17-19]. Oils, terpenoids, sugars, and volatile oils are also present along with pentacyclic triterpene acids, i.e. -boswellic acid, 3-acetyl--boswellic acid, 11-keto--boswellic acid and 3-acetyl-11-keto--boswellic acid [20-22]. The gummy resin has been traditionally used in the Ayurvedic system of medicine as an anti-arthritic, 
antiseptic, astringent, and as an expectorant. However, there is a shortage of in vivo trial of Boswellia serrata [23-26]. In this context, the proposed work was undertaken with an aim to evaluate the efficiency of Boswellia serrata, for its immunomodulatory and antioxidant potential in animal model.

\section{Materials and Methods}

\subsection{Collection and Preparation of Test Material}

The plant specimens were collected from Vindhya herbals, Bhopal (M.P). Boswellia serrata Roxb. identified from a voucher specimen (Vindhya herbals no.- 22) in Herbarium.

Chemicals and standards: The specimens of the sample were deposited at M.P Council of Science \& Technology, Madhya Pradesh, India, for its phytochemical study. $B$. serrata gum resin contains five major constituents, which were keto boswellic acid, 3-O-Acetyl 11-keto ß-boswellic acid, a-Boswellic acid, ß-Boswellic acid, 3-O-Acetyl-11-boswellic acid and 3-O-Acetyl-ß-boswellic acid. As a reference standard, a-Boswellic acid was purchased from Sigma-Aldrich. The purity of reference standards was $>98 \%$ (Confirmed with HPLC, at M.P Council of Science \& Technology, Madhya Pradesh, India).

Preparation of standard stock and working solutions: Extraction was done by maceration. $1 \mathrm{~kg}$ Boswellia serrata Roxb gum resin was soaked in ethanol (Sigma-Aldrich) in an amber-colored bottle for 3 days with occasional shaking and filtered. The filtrate was concentrated using evaporator. The dried extract was stored at $4^{\circ} \mathrm{C}$ for in vivo studies. Accurately weighed $2 \mathrm{mg}$ of reference standards were dissolved in ethanol to obtain concentration of $2.0 \mathrm{mg} / \mathrm{mL}$.

The percentage yield of the extract was determined [27].

$\%$ Yield of the extract $=\mathrm{Bx} / \mathrm{By}$ X 100

Where, $\mathrm{Bx}=$ Boswellia weight after extraction process $\mathrm{By}=$ Boswellia material weight taken for extraction

\subsection{In vivo Study}

\subsubsection{Animal Model}

Experimental Swiss Albino mice, (Mus musculus L.; Age/ Weight/ Size: 3-8 weeks old; 24-30 g) of either sex were obtained from National Institute of Nutrition, Hyderabad and were acclimatized for 3-4 weeks in the animal house of Jawaharlal Nehru Cancer Hospital and Research Centre, Bhopal. They were maintained under controlled conditions at humidity $60 \pm 10 \%$, temperature of $22 \pm 2{ }^{\circ} \mathrm{C}$, and a $12 / 12$ hour light/dark cycle. All experimental protocols were approved by Committee for the Protection and Control and Supervision of Experimental Animals (CPCSEA), prior to beginning the experiments. The Registration No. is 500/01/a/CPCSEA/2001. (Reference no. 670/225-IAEC /2008/Project no. 49).

\subsubsection{Macrophage Activation}

Group Treatments and Dosing of Animals

Mice were divided into six groups (no. of animals per group, $n=6$ ). Doses were decided according to LD50.

\begin{tabular}{|c|c|l|}
\hline Groups & Treatment & \multicolumn{1}{c|}{ Dosing } \\
\hline I & C & $\begin{array}{l}\text { Served as control without yeast. It does } \\
\text { not receive any dose of extracts, but was } \\
\text { injected with cold phosphate buffer } \\
\text { saline. Its peritoneal fluid was not } \\
\text { incubated with heat inactivated yeast } \\
\text { cells during harvesting. }\end{array}$ \\
\hline II & CY & $\begin{array}{l}\text { Served as control with yeast. It does not } \\
\text { receive any dose of extracts, but was } \\
\text { injected with cold phosphate buffer } \\
\text { saline. Its peritoneal fluid was } \\
\text { coincubated with heat inactivated yeast } \\
\text { cells during harvesting. }\end{array}$ \\
\hline III & Bs1 & $\begin{array}{l}\text { Received an oral dose of Boswellia } \\
\text { serrata extract (dose } 50 \mathrm{mg} / \mathrm{kg} \text { of mice } \\
\text { body weight) for five consecutive days. }\end{array}$ \\
\hline IV & Bs2 & $\begin{array}{l}\text { Received an oral dose of Boswellia } \\
\text { serrata extract (dose } 100 \mathrm{mg} / \mathrm{kg} \text { of mice } \\
\text { body weight) for five consecutive days }\end{array}$ \\
\hline V & Bs3 & $\begin{array}{l}\text { Received an oral dose of Boswellia } \\
\text { serrata extract (dose } 150 \mathrm{mg} / \mathrm{kg} \text { of mice } \\
\text { body weight) for five consecutive days. }\end{array}$ \\
\hline DMSO & $\begin{array}{l}\text { Received an oral dose of Dimethyl } \\
\text { sulfoxide (DMSO) } 35 \text { mg/kg body } \\
\text { weight) for five consecutive days }\end{array}$ \\
\hline
\end{tabular}

Chemicals used were: Phosphate buffer saline, RPMI-1640 medium (16.3 g RPMI-1640 powder was added to $900 \mathrm{~mL}$ sterilized Double Distilled Water) and 1.4 g sodium bicarbonate was incorporated in it. The solution was filtered by using filtration assembly (Sartorius). To the filtrate $20 \mathrm{~mL}$ penstrep (penicillin streptomycin) solution and few drops of gentamycin was added. This is called as RPMI-1640 incomplete medium. To make it a complete medium, $15 \%$ FCS was added and at $-5^{\circ} \mathrm{C}$ to $-20{ }^{\circ} \mathrm{C}$. in deep freezer, Cornoys fixative was prepared as acetic acid: methanol (1:3) and kept at $4{ }^{\circ} \mathrm{C}$; Giemsa stain (1g giemsa powder was added to $50 \%$ glycerol in methanol) and incubated in water bath for 1 hour at $60^{\circ} \mathrm{C}$ and stirred overnight using a magnetic bead. Working solution (freshly prepared) $5 \mathrm{~mL}$ stock solution was added to $45 \mathrm{~mL}$ DDW and buffer solutions. Inactivated yeast suspension (Yeast packet was purchased from the local market and 15 balls of yeast were suspended in $2 \mathrm{ml}$ DDW). This suspension was kept in hot air oven at $57^{\circ} \mathrm{C}$ for 45 minutes in order to prepare inactivated yeast suspension. Dimethyl Sulfoxide (DMSO) was taken as a reference standard ( $0.5 \%$ in RPMI medium) and provided as $35 \mathrm{mg} / \mathrm{kg}$ body weight of mice as an oral dose [28].

\section{Procedure}

Mice were orally fed with different doses of drugs, 
regularly for five days. Peritoneal fluid was isolated from the treated and control mice after 24 hours by injecting $8-10 \mathrm{~mL}$ of cold phosphate buffer saline. After 5 minutes of injection, the abdomen was gently massaged. Peritoneal fluid was aspirated and centrifuged at $1400 \mathrm{rpm}$ for 15 minutes. Supernatant was discarded and pellet was suspended in $5 \mathrm{~mL}$ RPMI-1640 medium. About 1 drop of gentamycin was added to the medium. This culture was co-incubated for 24 hours at $37^{\circ} \mathrm{C}$ in $5 \% \mathrm{CO}_{2}$ incubator. After the desired time, harvesting of cell was done in which culture was co-incubated with heat inactivated yeast. After 30 minutes, it was centrifuged at $1400 \mathrm{rpm}$ for $20 \mathrm{~min}$. This process was repeated after 60 minutes, 90 minutes, 120 minutes, 150 minutes and 180 minutes. The resultant pellet was fixed in Conroy's fixative and smear was prepared on clean glass slide. The slide was air-dried and was stained with Giemsa for $10 \mathrm{~min}$. One hundred macrophages were scanned from each of the test and control smears. The macrophage cells with ingested yeast cells were counted. This was expressed as percentage phagocytosis or percentage inhibition of yeast digestion which was calculated by formula: \% Inhibition of yeast digestion $=$ No. of active macrophages/ Total no. of macrophages $\times 100$ [28].

\subsubsection{Intracellular Killing Capacity}

Different stages of phagocytotic activity of macrophages against yeast were observed under $40-\mathrm{x}$ magnification using light microscope. While counting these macrophages with phagocytosed yeast, a record of all intracellular forms of yeast were maintained. Two forms were observed; (a) yeast cells with homogenous blue cytoplasm, and (b) yeast cells with partially or completely decolorized cytoplasm (killed/digested organisms by macrophages are called as ghost cells). The intracellular killing capacity (ICK) was expressed as the number of ghost cells present per 100 phagocytosed yeast cells [29].

\subsubsection{Preparation of Mice Liver Homogenate}

Six mice were selected for the study. Three mice were sensitized with $100 \mu \mathrm{g}$ of egg albumin, adsorbed in $12 \mathrm{mg}$ of aluminium hydroxide gel prepared in $0.5 \mathrm{~mL}$ of saline, for five days and were sacrificed, dissected and their abdominal cavity was perfused with $0.9 \%$ saline. Whole liver was taken out and was processed to get $10 \%$ homogenate in cold phosphate buffered saline, $\mathrm{pH}$ 7.4, using glass Teflon homogenizer. It was then filtered to get a clear homogenate [30].

\subsubsection{Activity of non-enzyme Antioxidant, Reduced Glutathione Assay (GSH)}

As per the method described by Ellman [28], the activity of non-enzyme antioxidant was measured. Enzymatic content in tissues was measured spectrophotometrically at $412 \mathrm{~nm}$ using Ellman's reagent (DTNB;5, 5' dithiodinitrobenzoic acid) as a coloring agent. DTNB reacts with glutathione to generate 2-nito, 5-thiobenzoic acid which is a yellow coloured complex.0.2 $\mathrm{mL}$ of mice liver homogenate was collected and dissolved in $1.8 \mathrm{~mL}$ Double Distilled Water. Liver homogenate was added to different concentrations of the extracts $(200,500$ and $1000 \mu \mathrm{g} / \mathrm{mL}$ ). $3 \mathrm{~mL}$ of precipitating solution was added and allowed to stand for 5 minutes to form a precipitate. $2 \mathrm{~mL}$ of the filtrate was added to $8 \mathrm{~mL}$ phosphate buffer. $1 \mathrm{~mL}$ of DTNB was added to the above solution so that a yellow colour was developed. Absorbance was measured at 412 $\mathrm{nm}$ with the help of spectrophotometer. The percentage reduction was calculated by comparison with the control using the formula: Percentage reduction (\%): Absorbance (Control) - Absorbance (Test sample)/ Absorbance $($ Control $) \times 100[31]$.

\subsubsection{Activity of Antioxidant Enzyme Glutathione Peroxidase (GPx)}

Liver homogenate, as prepared in the GSH assay, was added to different concentrations of the extracts $(200,500$ and $1000 \mu \mathrm{g} / \mathrm{mL}$ ). Reaction mixture contained $0.2 \mathrm{~mL}$ of $0.4 \mathrm{M}$ Tris- $\mathrm{HCl}$ buffer $(\mathrm{pH} 7.0), 0.1 \mathrm{~mL}$ of $10 \mathrm{mM}$ sodium azide, $0.2 \mathrm{~mL}$ of tissue homogenate (homogenized in $0.4 \mathrm{M}$, Tris- $\mathrm{HCl}$ buffer, $\mathrm{pH} 7.0$ ), $0.2 \mathrm{~mL}$ glutathione, and $0.1 \mathrm{~mL}$ of $0.2 \mathrm{mM}$ hydrogen peroxide. The contents were incubated at $37^{\circ} \mathrm{C}$ for 10 minutes. The reaction was arrested by adding $0.4 \mathrm{~mL}$ of $10 \%$ TCA, and centrifuged. Supernatant was assayed for glutathione content by using Ellmans reagent (19.8mg of 5,5'-dithiobisnitro benzoic acid (DTNB) in 100 $\mathrm{mL}$ of $0.1 \%$ sodium nitrate). The percentage reduction was calculated by comparison with the control using the formula of Percentage reduction (\%): Absorbance (Control) - Absorbance (Test sample)/ Absorbance (Control) $\times 100$ [31].

\subsubsection{Assay of Lipid Peroxidation}

The degree of lipid peroxidation was evaluated by estimating the thiobarbituric acid--reactive substances (TBARS). Chemicals used were: 5,5'-dithiodinitrobenzoic acid (DTNB), Acetic acid, Ethelene Diamine Tetracetic Acid (EDTA), Ferrous sulphate $\left(\mathrm{FeSO}_{4}\right)$, Phosphoric acid, Thiobarbituric acid (TBA), Trichloroacetic acid (TCA). Different concentrations $(200-1000 \mu \mathrm{g} / \mathrm{mL})$ of Bs was added to the liver homogenate prepared by same procedure as in GSH assay. Lipid peroxidation was initiated by adding $100 \mu \mathrm{L}$ of $15 \mathrm{mM} \mathrm{FeSO}_{4}$ solution to $3 \mathrm{~mL}$ of liver homogenate. After 30 minutes, $100 \mu \mathrm{g}$ of this reaction mixture was taken in a tube containing $1.5 \mathrm{~mL}$ of $10 \%$ TCA. After 10 minutes, tubes were centrifuged and supernatant was separated and mixed with $1.5 \mathrm{~mL}$ of $10 \%$ TBA in $50 \%$ acetic acid. The mixture was then be heated in a hot water bath at $85^{\circ} \mathrm{C}$ for 30 min to complete the reaction. The intensity of pink coloured complex formed was measured at $535 \mathrm{~nm}$ in a spectrophotometer. The percentage inhibition of lipid peroxidation was calculated by comparing the results of the rest with those of controls 
not treated with the extracts, as per the following formula [32]:

Inhibition Percentage $(\%)=$ Absorbance $($ Control $)-$ Absorbance (Test sample)/ Absorbance (Control) $\times 100$.

\subsection{Statistical Analysis}

All the data were expressed as mean \pm standard error of mean (SEM) of six independent experiments performed under the same condition. All data were analyzed with a confidence level of $95 \%(\alpha=0.05)$ and $99 \%(\alpha=0.01)$. Two-way ANOVA was used to make a statistical comparison among the groups and treatments using statistical software origin- 8 version. Results with $p<0.05$ and $p<0.01$ were considered statistically significant.

\section{Results}

Table 1. Characteristic features of the collected medicinal plant materials

\begin{tabular}{|c|c|}
\hline Plant Name & Boswellia serrata Roxb. \\
\hline Plant part & gum (dry extract) \\
\hline Appearance & powder (500g) \\
\hline Colour & greenish yellow \\
\hline Taste and aroma & Characteristic \\
\hline Solubility & soluble in alcohol and in hot water \\
\hline $\begin{array}{c}\text { Weight of the extract } \\
\text { obtained }\end{array}$ & $52 \mathrm{~g}$ \\
\hline $\begin{array}{c}\text { Percentage yield of the } \\
\text { extract obtained }\end{array}$ & $66.16 \%$ \\
\hline
\end{tabular}

\subsection{Macrophage Activation}

A non-specific immune response was stimulated as indicated by the activation of macrophages by Bs extracts. The enhanced phagocytic efficacy of the macrophages was seen as more engulfment of yeast cells. This increase in the phagocytic activity was a significant dose related increase as observed in mice treated with the highest dose of the Bs extract. There was a significant increase in the percentage inhibition of yeast digestion in the peritoneal fluid of mice, that received highest dose of Bs extract, at a significant level of $p<0.01$ compared to that of the controls (Table 2).

In order to determine whether treatment with extracts exerted any long-term effects, the activity of macrophages was measured after different duration of incubation of peritoneal fluid. The effect of doses of extracts to stimulate macrophages was assessed after 30 minutes, 60 minutes, 90 minutes, 120 minutes, 150 minutes, and 180 minutes of incubation with the yeast cells. Morphologically, macrophages from drug-treated animals appeared more activated and showed all the stages of phagocytosis, with increasing duration of incubation from 30 minutes to 180 minutes. The greatest macrophage activation was observed after 180 minutes. This might be because macrophages need some time to become fully activated for complete phagocytosis. The cells which ingested three or more yeast particles were taken as positive and called as active macrophages. The percentage of phagocytosis was determined by counting 100 cells. The yeast ingesting capacity of macrophages, when expressed in terms of percentage phagocytosis, was increased with duration of incubation. The increase was more rapid with higher doses among different groups of extracts treated mice. The number of macrophages with one, two, three and more yeast cells was also counted after every 30 minutes of incubation. After 30 minutes and 60 minutes of incubation, the number of active macrophages with more than three yeast cells were none, which means that macrophages did not reached a stage to engulf a greater number of yeast cells within 60 minutes. The number of macrophages with one, two, three or more yeast cells was also found to increase in a dose dependent manner with macrophages of Bs 3 group engulfing the maximum number of yeast cells thereby reflecting a greater number of active macrophages.

Also, it was observed that the phagocytic activity, i.e., the number of yeast cells ingested per macrophage also increases with incubation time. During the incubation time, the phagocytic process showed all the phases from the initial phase to the engulfing phase and finally to the digested phase. The engulfing phase shows a greater number of yeast particles ingested and then digested. This increase in number of yeast cells was dose dependent. Hence, it was noted that the process of phagocytosis of more yeast particles increases with time. From the present investigation, it was also noticed that at the end of 180 minutes of incubation, the number of yeast cells per macrophages (phagocytic activity, Table 2) were more than 18 per macrophage and reached to a $68.63 \pm 0.33$ (Bs3), as comparable to the standard with $68.40 \pm 0.33$. indicating that one macrophage can engulf even more than 20 yeast at a time. This phagocytic activity was found maximum in cases of Bs3, Bs2, \& Bs1 groups with more than 20 yeast cells per macrophage after $180 \mathrm{~min}$.

Table 2A. Effect of extracts on activation of macrophages after $30 \mathrm{~min}$ of incubation with yeast cells

\begin{tabular}{|c|c|c|c|}
\hline & \multicolumn{3}{|c|}{ Percentage Phagocytosis (\%) } \\
\hline $\begin{array}{c}\text { Groups } \\
\text { (treatment) }\end{array}$ & $\begin{array}{c}\text { With } \\
\text { 1 yeast cell }\end{array}$ & $\begin{array}{c}\text { With } \\
\text { 2 yeast cells }\end{array}$ & $\begin{array}{c}\text { With } \\
\text { 3 yeast cells }\end{array}$ \\
\hline $\mathrm{CY}$ & $0 \pm 0$ & $11 \pm 0$ & $1.666 \pm 0$ \\
\hline $\mathrm{Bs} 1$ & $12.1 \pm 0.167$ & $11.3 \pm 0$ & $1.33 \pm 0$ \\
\hline $\mathrm{Bs} 2$ & $16.1 \pm 0.1$ & $10.66 \pm 0$ & $3.6 \pm 0$ \\
\hline $\mathrm{Bs} 3$ & $26.64 \pm 0.0$ & $2.33 \pm 0$ & $2.66 \pm 0$ \\
\hline $\mathrm{DMSO}$ & $35.2 \pm 0.11$ & $15.6 \pm 0$ & $1.666 \pm 0$ \\
\hline
\end{tabular}

Results expressed in Mean \pm SEM; Replicates: 6

All the results were statistically significant at $\mathrm{p}<0.05$ and $\mathrm{p}<0.01$ CY: Control with yeast;

- Bs 1: Boswellia serrata extract (dose $50 \mathrm{mg} / \mathrm{kg}$ of mice body weight);

- Bs2: Boswellia serrata extract (dose $100 \mathrm{mg} / \mathrm{kg}$ of mice body weight);

- Bs3: Boswellia serrata extract (dose $150 \mathrm{mg} / \mathrm{kg}$ of mice body weight);

DMSO: Dimethyl sulfoxide (DMSO) (35 mg/kg body weight) 
Table 2B. Effect of extracts on activation of macrophages after $60 \mathrm{~min}$ of incubation with yeast cells

\begin{tabular}{|c|c|c|c|c|c|}
\hline $\begin{array}{c}\text { Groups } \\
\text { (treatment) }\end{array}$ & $\begin{array}{c}\text { With } \\
1 \\
\text { yeast } \\
\text { cell }\end{array}$ & $\begin{array}{c}\text { With } \\
2 \\
\text { yeast } \\
\text { cells }\end{array}$ & $\begin{array}{c}\text { With } \\
3 \\
\text { yeast } \\
\text { cells }\end{array}$ & $\begin{array}{c}\text { With }>3 \\
\text { yeast } \\
\text { cells }\end{array}$ & $\begin{array}{l}\text { Total no. of } \\
\text { macrophages }\end{array}$ \\
\hline CY & $\begin{array}{c}23.64 \\
\pm \\
0.02\end{array}$ & $\begin{array}{c}11.44 \\
\pm \\
0.22\end{array}$ & $2 \pm 0$ & - & $37.088 \pm 0.1$ \\
\hline Bs1 & $\begin{array}{c}16.53 \\
\pm \\
0.06 \\
\end{array}$ & $\begin{array}{c}11.66 \\
\pm \\
0.33 \\
\end{array}$ & $4 \pm 0$ & - & $32.2 \pm 0.33$ \\
\hline Bs2 & $\begin{array}{c}18.36 \\
\pm \\
0.06\end{array}$ & $\begin{array}{c}15.33 \\
\pm \\
0.33\end{array}$ & $\begin{array}{c}4.4 \pm \\
0.2\end{array}$ & - & $38.1 \pm 0.33$ \\
\hline Bs3 & $\begin{array}{c}28.66 \\
\pm \\
0.06 \\
\end{array}$ & $\begin{array}{c}9.22 \\
\pm \\
0.11\end{array}$ & $\begin{array}{c}3.2 \pm \\
0.1\end{array}$ & - & $41.08 \pm 0.1$ \\
\hline DMSO & $\begin{array}{c}37.26 \\
\pm \\
0.26\end{array}$ & $\begin{array}{r}14.4 \\
\pm 0.2\end{array}$ & $\begin{array}{c}4.2 \pm \\
0.1\end{array}$ & - & $55.86 \pm 0.33$ \\
\hline
\end{tabular}

Result expressed in Mean \pm SEM; Replicates: 6

All the results were statistically significant at $\mathrm{p}<0.05$ and $\mathrm{p}<0.01$

CY: Control with yeast;

- Bs1: Boswellia serrata extract (dose $50 \mathrm{mg} / \mathrm{kg}$ of mice body weight);

- Bs2: Boswellia serrata extract (dose $100 \mathrm{mg} / \mathrm{kg}$ of mice body weight);

- Bs3: Boswellia serrata extract (dose $150 \mathrm{mg} / \mathrm{kg}$ of mice body weight);

- $\quad$ DMSO: Dimethyl sulfoxide (DMSO) (35 $\mathrm{mg} / \mathrm{kg}$ body weight)

Table 2C. Effect of extracts on activation of macrophages after $90 \mathrm{~min}$ of incubation

\begin{tabular}{|c|c|c|c|c|c|}
\hline & \multicolumn{5}{|c|}{ Percentage Phagocytosis (\%) } \\
\hline $\begin{array}{c}\text { Groups } \\
\text { (treatment) }\end{array}$ & $\begin{array}{c}\text { With } \\
1 \\
\text { yeast } \\
\text { cell }\end{array}$ & $\begin{array}{c}\text { With } \\
2 \\
\text { yeast } \\
\text { cells }\end{array}$ & $\begin{array}{c}\text { With } \\
3 \\
\text { yeast } \\
\text { cells }\end{array}$ & $\begin{array}{c}\text { With }>3 \\
\text { yeast } \\
\text { cells }\end{array}$ & $\begin{array}{c}\text { Total } \\
\text { number of } \\
\text { active } \\
\text { macrophages }\end{array}$ \\
\hline CY & $\begin{array}{c}25.22 \\
\pm \\
0.11\end{array}$ & $\begin{array}{l}12.33 \\
\pm 0.3\end{array}$ & $\begin{array}{r}11.4 \\
\pm 0.2\end{array}$ & $2 \pm 0$ & $50.95 \pm 0.1$ \\
\hline Bs1 & $\begin{array}{c}18.07 \\
\pm \\
0.07\end{array}$ & $\begin{array}{l}13.33 \\
\pm 0.3\end{array}$ & $\begin{array}{c}9.2 \pm \\
0.1\end{array}$ & $4 \pm 0$ & $44.60 \pm 0.000$ \\
\hline Bs2 & $\begin{array}{c}20.07 \\
\pm \\
0.07\end{array}$ & $\begin{array}{l}15.66 \\
\pm 0.3\end{array}$ & $\begin{array}{c}9.33 \\
\pm \\
0.33\end{array}$ & $4.6 \pm 0$ & $49.67 \pm 0.000$ \\
\hline Bs3 & $\begin{array}{c}37.08 \\
\pm \\
0.08\end{array}$ & $\begin{array}{l}3.33 \\
\pm 0.3\end{array}$ & $\begin{array}{c}11.33 \\
\pm \\
0.33\end{array}$ & $3 \pm 0$ & $45.74 \pm 0.001$ \\
\hline DMSO & $\begin{array}{c}37.07 \\
\pm \\
0.07\end{array}$ & $\begin{array}{c}17 \pm \\
0\end{array}$ & $\begin{array}{c}7.4 \pm \\
0.2\end{array}$ & $4 \pm 0$ & $55.47 \pm 0.037$ \\
\hline
\end{tabular}

Results expressed in Mean \pm SEM; Replicates: 6

All the results were statistically significant at $\mathrm{p}<0.05$ and $\mathrm{p}<0.01$

- CY: Control with yeast;

- Bs1: Boswellia serrata extract (dose $50 \mathrm{mg} / \mathrm{kg}$ of mice body weight);

- Bs2: Boswellia serrata extract (dose $100 \mathrm{mg} / \mathrm{kg}$ of mice body weight);

- Bs3: Boswellia serrata extract (dose $150 \mathrm{mg} / \mathrm{kg}$ of mice body weight);

- DMSO: Dimethyl sulfoxide (DMSO) (35 mg/kg body weight)
Table 2D. Effect of extracts on activation of macrophages after $120 \mathrm{~min}$ of incubation with yeast cells.

\begin{tabular}{|c|c|c|c|c|c|}
\hline & \multicolumn{5}{|c|}{ Percentage Phagocytosis (\%) } \\
\hline $\begin{array}{c}\text { Groups } \\
\text { (treatment) }\end{array}$ & $\begin{array}{c}\text { With } \\
1 \\
\text { yeast } \\
\text { cell }\end{array}$ & $\begin{array}{c}\text { With } \\
2 \\
\text { yeast } \\
\text { cells }\end{array}$ & $\begin{array}{c}\text { With } \\
3 \\
\text { yeast } \\
\text { cells } \\
\end{array}$ & $\begin{array}{c}\text { With }>3 \\
\text { yeast } \\
\text { cells }\end{array}$ & $\begin{array}{c}\text { Total } \\
\text { number of } \\
\text { active } \\
\text { macrophages }\end{array}$ \\
\hline CY & $\begin{array}{c}27.22 \\
\pm \\
0.11\end{array}$ & $\begin{array}{r}13.1 \\
\pm 0.1\end{array}$ & $\begin{array}{c}7.01 \\
\pm \\
0.016\end{array}$ & $2 \pm 0$ & $49.33 \pm 0.003$ \\
\hline Bs1 & $\begin{array}{c}22.61 \\
\pm \\
0.08\end{array}$ & $\begin{array}{c}5.01 \\
\pm \\
0.01\end{array}$ & $\begin{array}{l}7.00 \\
\pm 00\end{array}$ & $3 \pm 0$ & $37.63 \pm 0.003$ \\
\hline Bs2 & $\begin{array}{c}18.22 \\
\pm \\
0.11\end{array}$ & $\begin{array}{c}13.00 \\
\pm \\
0.003\end{array}$ & $\begin{array}{c}4.44 \\
\pm \\
0.22\end{array}$ & $4 \pm 0$ & $39.66 \pm 0.000$ \\
\hline Bs3 & $\begin{array}{c}26.44 \\
\pm \\
0.22\end{array}$ & $\begin{array}{c}14.06 \\
\pm \\
0.066\end{array}$ & $\begin{array}{l}8.00 \\
\pm 00\end{array}$ & $1 \pm 0$ & $48.50 \pm 0.003$ \\
\hline DMSO & $\begin{array}{c}42.18 \\
\pm \\
0.08\end{array}$ & $\begin{array}{c}16.01 \\
\pm \\
0.01\end{array}$ & $\begin{array}{c}8.007 \\
\pm 00\end{array}$ & $12 \pm 0$ & $48.20 \pm 0.00$ \\
\hline
\end{tabular}

Results expressed in Mean \pm SEM; Replicates: 6

All the results were statistically significant at $p<0.05$ and $p<0.01$

- CY: Control with yeast;

- Bs1: Boswellia serrata extract (dose $50 \mathrm{mg} / \mathrm{kg}$ of mice body weight);

- Bs2: Boswellia serrata extract (dose $100 \mathrm{mg} / \mathrm{kg}$ of mice body weight);

- Bs3: Boswellia serrata extract (dose $150 \mathrm{mg} / \mathrm{kg}$ of mice body weight);

- DMSO: Dimethyl sulfoxide (DMSO) (35 mg/kg body weight)

Table 2E. Effect of extracts on activation of macrophages after $150 \mathrm{~min}$ of incubation with yeast cells

\begin{tabular}{|c|c|c|c|c|c|}
\hline & \multicolumn{5}{|c|}{ Percentage Phagocytosis (\%) } \\
\hline $\begin{array}{c}\text { Groups } \\
\text { (treatment) }\end{array}$ & $\begin{array}{c}\text { With } 1 \\
\text { yeast } \\
\text { cell }\end{array}$ & $\begin{array}{l}\text { With } 2 \\
\text { yeast } \\
\text { cells }\end{array}$ & $\begin{array}{c}\text { With } \\
3 \\
\text { yeast } \\
\text { cells }\end{array}$ & $\begin{array}{c}\text { With }>3 \\
\text { yeast } \\
\text { cells }\end{array}$ & $\begin{array}{c}\text { Total } \\
\text { number of } \\
\text { active } \\
\text { macrophages }\end{array}$ \\
\hline $\mathbf{C Y}$ & $\begin{array}{c}28.44 \\
\pm 0.22\end{array}$ & $\begin{array}{l}12.333 \\
\pm 0.66\end{array}$ & $\begin{array}{c}7.33 \\
\pm \\
0.33\end{array}$ & $2 \pm 0$ & $50.1 \pm 0.0$ \\
\hline Bs1 & $\begin{array}{l}24.073 \\
\pm 0.07\end{array}$ & $\begin{array}{r}6.333 \\
\pm 0.33 \\
\end{array}$ & $7 \pm 1$ & $3 \pm 0$ & $40.40 \pm 0.0$ \\
\hline Bs2 & $\begin{array}{l}18.073 \\
\pm 0.07\end{array}$ & $\begin{array}{l}13.333 \\
\pm 0.33\end{array}$ & $\begin{array}{c}5 \pm \\
0.00\end{array}$ & $4 \pm 0$ & $40.40 \pm 0.0$ \\
\hline Bs3 & $\begin{array}{l}24.046 \\
\pm 0.04\end{array}$ & $\begin{array}{l}17.333 \\
\pm 0.33\end{array}$ & $\begin{array}{l}4 \pm \\
0.00\end{array}$ & $4 \pm 0$ & $56.38 \pm 0.0$ \\
\hline DMSO & $\begin{array}{l}30.166 \\
\pm 0.16 \\
\end{array}$ & $\begin{array}{l}7.333 \\
\pm 0.66 \\
\end{array}$ & $\begin{array}{l}12.67 \\
\pm 0.66 \\
\end{array}$ & $6 \pm 0$ & $56.16 \pm 0.0$ \\
\hline
\end{tabular}

Results expressed in Mean \pm SEM; Replicates: 6

All the results were statistically significant at $\mathrm{p}<0.05$ and $\mathrm{p}<0.01$

- CY: Control with yeast;

- Bs1: Boswellia serrata extract (dose $50 \mathrm{mg} / \mathrm{kg}$ of mice body weight);

Bs2: Boswellia serrata extract (dose $100 \mathrm{mg} / \mathrm{kg}$ of mice body weight);

Bs3: Boswellia serrata extract (dose $150 \mathrm{mg} / \mathrm{kg}$ of mice body weight);

DMSO: Dimethyl sulfoxide (DMSO) (35 mg/kg body weight) 
Table 2F. Effect of extracts on activation of macrophages after $180 \mathrm{~min}$ of incubation with yeast cells

\begin{tabular}{|c|c|c|c|c|c|}
\hline & \multicolumn{5}{|c|}{ Percentage Phagocytosis (\%) } \\
\hline $\begin{array}{c}\text { Groups (treat } \\
\text { ment) }\end{array}$ & With 1 yeast cell & $\begin{array}{c}\text { With 2 yeast } \\
\text { cells }\end{array}$ & $\begin{array}{c}\text { With 3 yeast } \\
\text { cells }\end{array}$ & With >3 yeast cells & Total no. of macrophages \\
\hline CY & $51.33 \pm 0.33$ & $29.33 \pm 0.33$ & $12.33 \pm 0.33$ & $3 \pm 0$ & $55.99 \pm 0.33$ \\
\hline Bs1 & $45.33 \pm 0.33$ & $25.66 \pm 0.33$ & $13 \pm 1$ & $3.6 \pm 0$ & $47.6 \pm 0.33$ \\
\hline Bs2 & $48.33 \pm 0.33$ & $34.66 \pm 0.33$ & $13.33 \pm 0.33$ & $1 \pm 0$ & $57.33 \pm 0.33$ \\
\hline Bs3 & $45.33 \pm 0.33$ & $37.33 \pm 0.33$ & $10.33 \pm 0.33$ & $4.6 \pm 0$ & $68.63 \pm 0.33$ \\
\hline DMSO & $65.33 \pm 0.33$ & $39.33 \pm 0.33$ & $18.73 \pm 0.13$ & $6.6 \pm 0$ & $68.40 \pm 0.33$ \\
\hline
\end{tabular}

Results expressed in Mean \pm SEM; Replicates: 6

All the results were statistically significant at $\mathrm{p}<0.05$ and $\mathrm{p}<0.01$

- CY: Control with yeast;

- Bs1: Boswellia serrata extract (dose $50 \mathrm{mg} / \mathrm{kg}$ of mice body weight);

- Bs2: Boswellia serrata extract (dose $100 \mathrm{mg} / \mathrm{kg}$ of mice body weight);

- Bs3: Boswellia serrata extract (dose $150 \mathrm{mg} / \mathrm{kg}$ of mice body weight);

- DMSO: Dimethyl sulfoxide (DMSO) (35 mg/kg body weight)

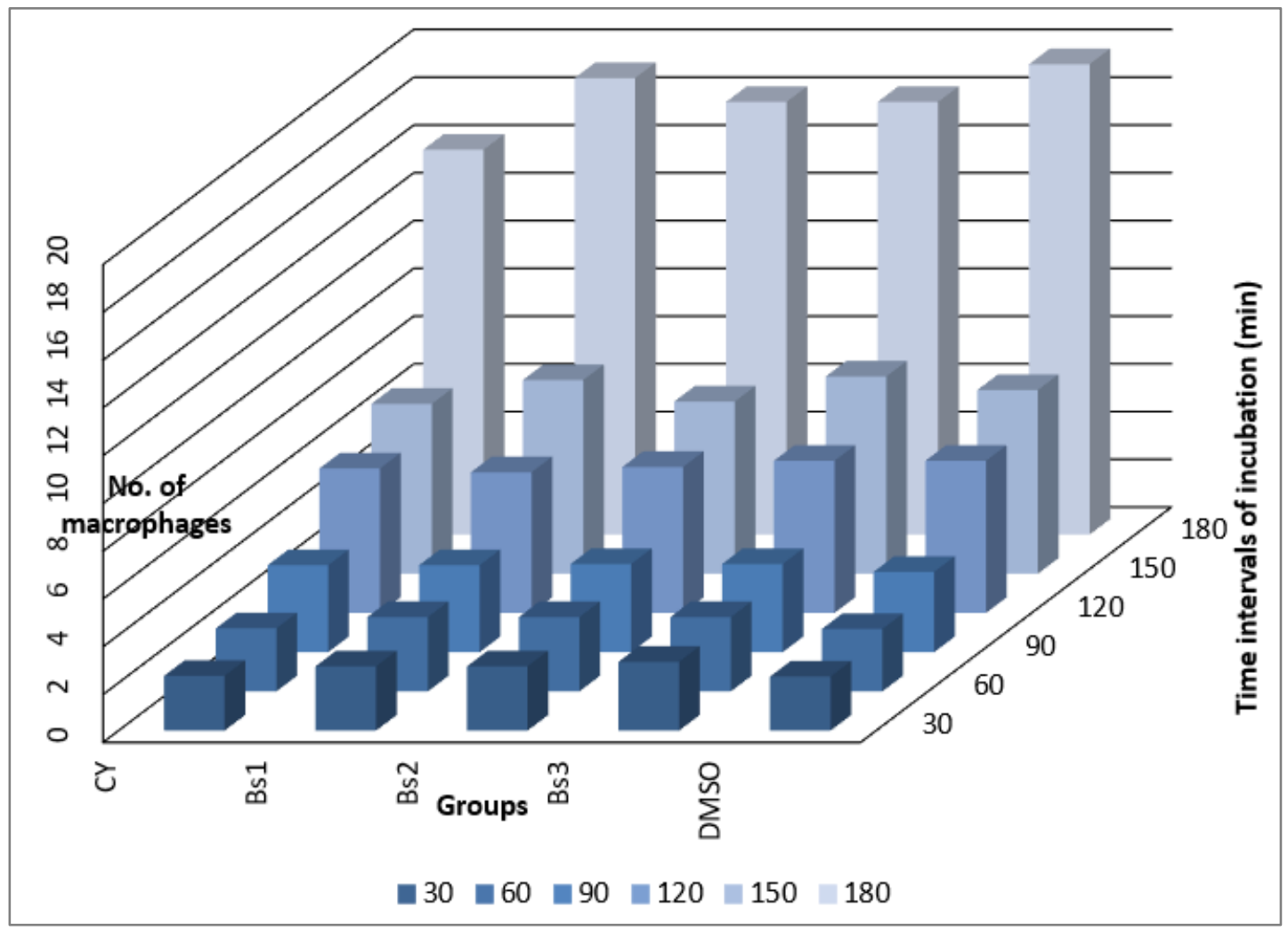

Results expressed in Mean \pm SEM; Replicates: 6

All the results were statistically significant at $\mathrm{p}<0.05$ and $\mathrm{p}<0.01$

- CY: Control with yeast;

- Bs1: Boswellia serrata extract (dose $50 \mathrm{mg} / \mathrm{kg}$ of mice body weight);

- Bs2: Boswellia serrata extract (dose $100 \mathrm{mg} / \mathrm{kg}$ of mice body weight);

- Bs3: Boswellia serrata extract (dose $150 \mathrm{mg} / \mathrm{kg}$ of mice body weight);

- DMSO: Dimethyl sulfoxide (DMSO) (35 mg/kg body weight)

Graph 1. Phagocytic activity of macrophages by Bs extracts at different incubation time 


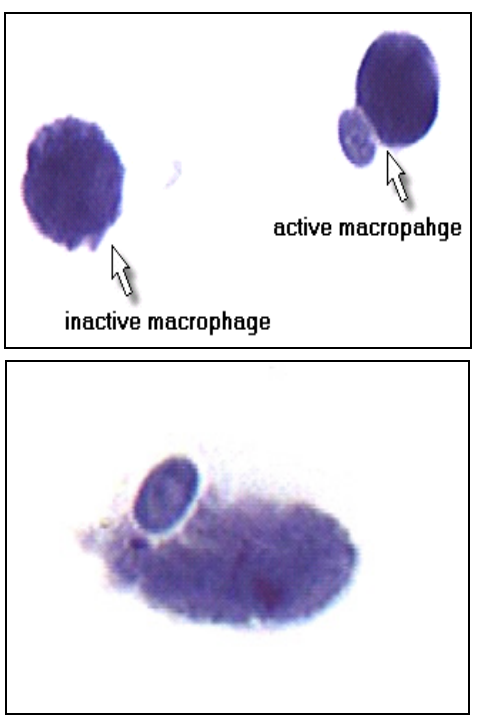

Figure 1. Macrophage activity in treated groups

\subsection{Intracellular Killing Capacity}

The number of ghost cells (Table 3) was also counted after every 30 minutes of incubation. Ghost cells were the number of completely digested yeast cells. This digestion starts after 90 minutes of incubation period. However, group Bs1 showed intracellular killing capacity (IKC) after 120 minutes of incubation with yeast cells. The number of ghost cells was expressed as intracellular killing capacity of a macrophage, which was also shown to increase in a dose dependent manner within the same group and also with time duration. This increase was statistically significant $(p<0.01)$ as compared to that of the control. Groups Bs2 and Bs3 showed the same number of ghost cells i.e. $1.33 \pm 0$ at 90 minutes, and $1.333 \pm 0.0$ at 120 minutes of incubation with yeast cells. However, the pattern of increase was different.

Table 3. Intracellular killing capacity of macrophages at different time intervals of incubation

\begin{tabular}{|c|c|c|c|c|}
\hline & \multicolumn{4}{|c|}{ Time intervals of incubation (min) } \\
\hline Groups & $\mathbf{3 0}$ & $\mathbf{6 0}$ & $\mathbf{9 0}$ & $\mathbf{1 2 0}$ \\
\hline CY & - & - & $0.0 \pm 0.0$ & $0.0 \pm 0.0$ \\
\hline Bs1 & - & - & $0.0 \pm 0.0$ & $1.333 \pm 0.0$ \\
\hline Bs2 & - & - & $1.333 \pm 0.0$ & $1.336 \pm 0.0$ \\
\hline Bs3 & - & - & $1.333 \pm 0.0$ & $1.566 \pm 0.0$ \\
\hline DMSO & - & - & $1.00 \pm 0.0$ & $1.66 \pm 0.0$ \\
\hline
\end{tabular}

Results expressed in Mean \pm SEM; Replicates: 6

All the results were statistically significant at $\mathrm{p}<0.05$ and $\mathrm{p}<0.01$

- CY: Control with yeast;

- Bs1: Boswellia serrata extract (dose $50 \mathrm{mg} / \mathrm{kg}$ of mice body weight);

- Bs2: Boswellia serrata extract (dose $100 \mathrm{mg} / \mathrm{kg}$ of mice body weight);

- Bs3: Boswellia serrata extract (dose $150 \mathrm{mg} / \mathrm{kg}$ of mice body weight);

- DMSO: Dimethyl sulfoxide (DMSO) (35 mg/kg body weight)

\subsection{Reduced Glutathione Assay (GSH)}

For assessing the free radical quenching ability of Boswellia serrata Roxb., (Bs) the content of glutathione (GSH) in liver homogenate was measured. The effect of Bs extracts and reference standard, alpha tocopherol was studied on the oxidation of reduced glutathione. It was observed in normal as well as in mice sensitized with egg albumin, at three concentrations i.e., $200 \mu \mathrm{g} / \mathrm{mL}, 500$ $\mu \mathrm{g} / \mathrm{mL} \& 1000 \mu \mathrm{g} / \mathrm{mL}$ in reduced glutathione assay, the positive activity was shown by a decrease in optical density and corresponding increase in the percentage of inhibition by the extract (Table 4). Results showed that maximum percentage of inhibition of the oxidation of reduced GSH was shown by Bs extract when taken in a concentration of $1000 \mu \mathrm{g} / \mathrm{mL}$, as $97.06 \pm 0.025 \%$ activities in normal group and $60.50 \pm 0.017 \%$ activities in sensitized group. This activity was comparable to that of alpha tocopherol with $98.07 \pm 0.030 \% \& 61.52 \pm 0.018 \%$ in normal and sensitized groups respectively at the same concentration. It was also observed that the sensitized groups showed less percentage of inhibition than that of the normal groups. Also, there was very less variation among different concentrations of extracts within the same group of treatment. Results were expressed in Mean \pm SEM, with six replicates for each group. Table 4 reveals that at $p<0.05$ and $\mathrm{p}<0.01$ level of significance, there was a significant difference within the population means of treatments and similarly, a significant difference was also seen between the population means of concentrations. The results showed that the Bs extract significantly inhibited the oxidation of reduced glutathione in a dose dependent manner as compared to that of the standard.

Table 4. Effect of different concentrations of Bs extract and alpha tocopherol on the content of reduced glutathione in normal and sensitized mice

\begin{tabular}{|c|c|c|c|}
\hline \multirow{2}{*}{ Treatments } & \multicolumn{3}{|c|}{ Concentration of extracts $(\boldsymbol{\mu g} / \mathbf{m L})$} \\
\cline { 2 - 4 } & $\mathbf{2 0 0}$ & $\mathbf{5 0 0}$ & $\mathbf{1 0 0 0}$ \\
\hline NC* $^{*}$ & $0 \pm 0$ & $0 \pm 0$ & $0 \pm 0$ \\
\hline SC $^{*}$ & $0 \pm 0$ & $0 \pm 0$ & $0 \pm 0$ \\
\hline N + Bs & $86.34 \pm 0.014$ & $88.30 \pm 0.011$ & $\begin{array}{c}97.171 \pm \\
0.01\end{array}$ \\
\hline S + Bs & $61.28 \pm 0.025$ & $61.85 \pm 0.022$ & $\begin{array}{c}62.736 \pm \\
0.022\end{array}$ \\
\hline N + AT & $90.16 \pm 0.014$ & $96.24 \pm 0.011$ & $\begin{array}{c}98.437 \pm \\
0.01\end{array}$ \\
\hline S + AT & $62.02 \pm 0.031$ & $62.24 \pm 0.029$ & $\begin{array}{c}62.786 \pm \\
0.02\end{array}$ \\
\hline
\end{tabular}

Results expressed in Mean \pm SEM;

All results are statistically significant at $p<0.05$ and $p<0.01$. Replicates: 6 ; *non significant at 0.05 level

N: Normal; S: Sensitized; NC: Normal Control; SC: Sensitized Control; Bs: Boswellia serrata; AT: Alpha Tocopherol 


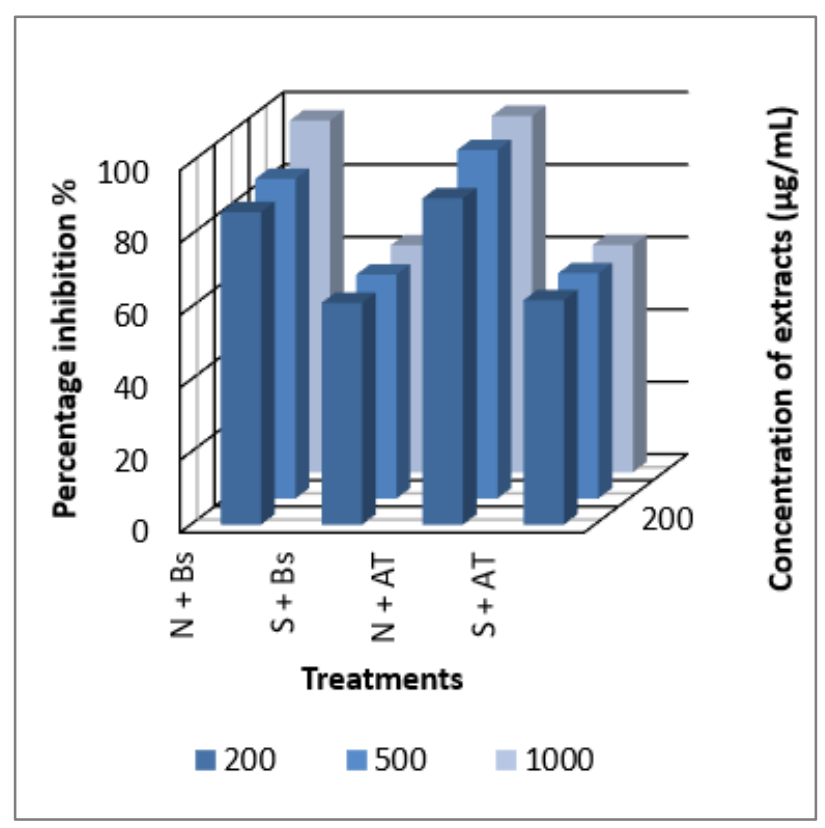

All results are statistically significant at $p<0.05$ and $p<0.01$. Replicates: 6; N: Normal; S: Sensitized; NC: Normal Control; SC: Sensitized Control; Bs: Boswellia serrata; AT: Alpha Tocopherol

Graph 2. Percentage inhibition of reduced glutathione by Boswellia serrata \& Alpha Tocopherol in normal and sensitized mice

\subsection{Activity of Antioxidant Enzyme, Glutathione Peroxidase (GPx)}

The free radical quenching activity of Bs extracts was also evaluated by studying its effect on the oxidation of antioxidant enzyme, glutathione peroxidase (GPx). Results showed that the activity increases in a concentration dependent manner, with an effective activity shown by Bs extract in both normal and sensitized groups. At $1000 \mu \mathrm{g} / \mathrm{mL}$, the Bs extract showed $91.171 \pm 0.01 \%$ and $60.54 \pm 0.0262 \%$ of inhibition of oxidation of glutathione peroxidase in normal and sensitized groups respectively. These results were very close to that of the standard, alpha tocopherol, having 92.122 $0 \% \& 61.56 \pm 0 \%$ of inhibition of oxidation of GPx in normal and sensitized groups respectively.

Again, it was observed that there was a large variation in the antioxidant activity of the extracts in normal and sensitized groups of mice. Statistical analysis showed that all the results were significant at 0.01 level, except the control groups of normal and sensitized groups which were not significant to each other (Table 5).
Table 5. Effect of Bs extract and alpha tocopherol on the content of Glutathione peroxidase in normal and sensitized mice

\begin{tabular}{|c|c|c|c|}
\hline & \multicolumn{3}{|c|}{ Concentration of extracts $(\boldsymbol{\mu g} / \mathbf{m L})$} \\
\hline Treatments & $\mathbf{2 0 0}$ & $\mathbf{5 0 0}$ & $\mathbf{1 0 0 0}$ \\
\hline NC* $^{*}$ & $0 \pm 0$ & $0 \pm 0$ & $0 \pm 0$ \\
\hline $\mathbf{S C}^{*}$ & $0 \pm 0$ & $0 \pm 0$ & $0 \pm 0$ \\
\hline \multirow{2}{*}{$\mathbf{N}+\mathbf{B s}$} & 81.842 & $85.151 \pm$ & $91.06 \pm$ \\
& \pm 0.007 & 0.040 & 0.025 \\
\hline \multirow{2}{*}{$\mathbf{S}+\mathbf{B s}$} & 59.939 & $60.158 \pm$ & $60.50 \pm$ \\
& \pm 0.086 & 0.027 & 0.017 \\
\hline \multirow{2}{*}{$\mathbf{N}+\mathbf{A T}$} & $85.475 \pm$ & $88.938 \pm$ & $92.07 \pm$ \\
& 0.014 & 0.034 & 0.030 \\
\hline \multirow{2}{*}{ S + AT } & $60.787 \pm$ & $61.151 \pm$ & $61.52 \pm$ \\
& 0.095 & 0.031 & 0.018 \\
\hline
\end{tabular}

Results expressed in Mean \pm SEM; Replicates: 6; *non significant at 0.05 level

Replicates: 6; N: Normal; S: Sensitized; NC: Normal Control; SC: Sensitized Control; Bs: Boswellia serrata; AT: Alpha Tocopherol

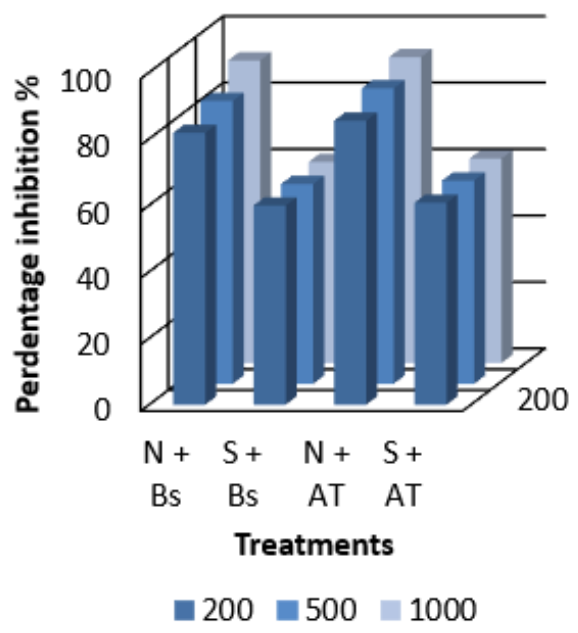

All results are statistically significant at $p<0.05$ and $p<0.01$. Replicates: 6; N: Normal; S: Sensitized; NC: Normal Control; SC: Sensitized Control; Bs: Boswellia serrata; AT: Alpha Tocopherol

Graph 3. Effect of the Bs extract on GPx

\subsection{Assay of Lipid Peroxidation}

The capacity of the Bs extract to inhibit the peroxidation of lipid in the mice liver tissues was also assessed as a measure of quenching free radicals or antioxidant activity. The Bs extract gave a dose dependent protection against lipid peroxidation in mice liver homogenate. As presented in the table, the extracts three different concentrations $(200 \mu \mathrm{g} / \mathrm{mL}, 500 \mu \mathrm{g} / \mathrm{mL}$ and $1000 \mu \mathrm{g} / \mathrm{mL})$ caused a significant decrease $(p<0.01)$ in the lipid peroxidation in the mice liver homogenate. 
However, Bs extract caused an effectively higher inhibition of the malondialdehyde (MDA) production in the liver tissues as compared to the positive control at the same concentration, at $1000 \mu \mathrm{g} / \mathrm{mL}$ as $92.815 \pm 0.02021 \%$ in normal mice \& $95.1233 \pm 0.1412 \%$ in sensitized mice, followed by alpha tocopherol having $89.631 \pm$ $0.02021 \%$ inhibition in normal mice \& $84.625 \pm 0.02021 \%$ inhibition in sensitized mice. Results were expressed in Mean \pm SEM. The experiment was performed in three replicates. Statistical analysis of the results showed a significant correlation between the concentration of the plant extracts and the capacity of inhibition of lipid peroxidation.

Table 6. Ferrous sulphate induced lipid peroxidation inhibition by Bs extract and alpha tocopherol at different concentrations in liver homogenate of normal and sensitized mice

\begin{tabular}{|c|c|c|c|}
\hline \multirow{2}{*}{ Treatments } & \multicolumn{3}{|c|}{ Concentration of extracts $(\mu \mathrm{g} / \mathrm{mL})$} \\
\cline { 2 - 4 } & 200 & 500 & 1000 \\
\hline \multirow{2}{*}{$\mathrm{SC}^{*}$} & $0 \pm 0$ & $0 \pm 0$ & $0 \pm 0$ \\
\hline \multirow{2}{*}{$\mathrm{N}+\mathrm{Bs}$} & $96.103 \pm 0$ & $0 \pm 0$ & $0 \pm 0$ \\
\hline \multirow{2}{*}{$\mathrm{S}+\mathrm{Bs}$} & 0.13279 & $98.268 \pm$ & $92.815 \pm$ \\
& $95.1 \pm$ & $97.268 \pm$ & $95.1233 \pm$ \\
\multirow{2}{*}{$\mathrm{N}+\mathrm{AT}$} & 0.13279 & 0.03753 & 0.1412 \\
& $77.436 \pm$ & $81.935 \pm$ & $89.631 \pm$ \\
\multirow{2}{*}{$\mathrm{S}+\mathrm{AT}$} & 76.13279 & 0.03753 & 0.02021 \\
& 0.13279 & $80.268 \pm$ & $84.625 \pm$ \\
& & 0.03753 & 0.02021 \\
\hline
\end{tabular}

Results expressed in Mean \pm SEM; Replicates: 6

All results are statistically significant at $p<0.05$ and $p<0.01$. N: Normal; S: Sensitized; NC: Normal Control; SC: Sensitized Control; Bs: Boswellia serrata; AT: Alpha Tocopherol

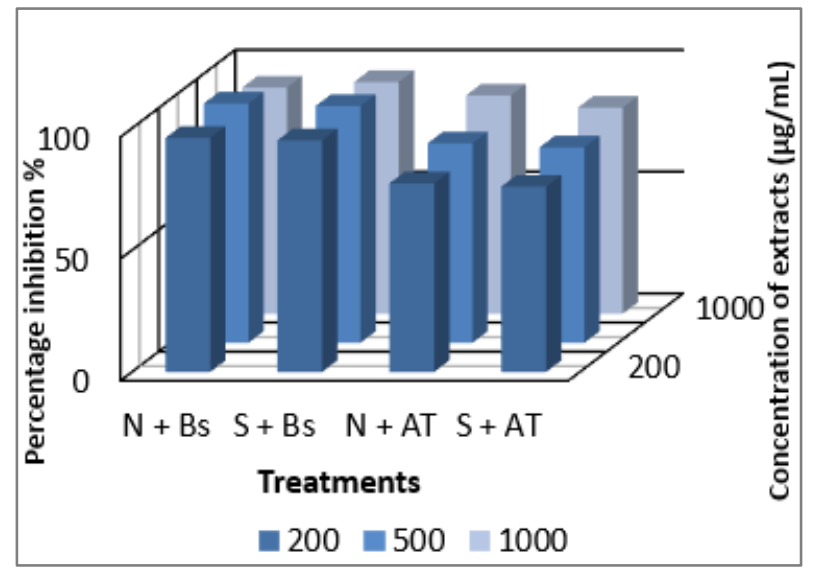

Results expressed in Mean \pm SEM; Replicates: 6

All results are statistically significant at $p<0.05$ and $p<0.01$. N: Normal; S: Sensitized; NC: Normal Control; SC: Sensitized Control; Bs: Boswellia serrata; AT: Alpha Tocopherol

Graph 4. Ferrous sulphate induced lipid peroxidation inhibition by Bs extract and alpha tocopherolat different concentrations in liver homogenate of normal and sensitized mice

\section{Discussion}

Inferring from the results of in vivo methods of quenching of free radicals, it can be said that the intracellular content of reduced glutathione enzyme, and prevention of lipid peroxidation in linoleic acid systems, by the extract of Boswellia serrata indicates that it has a primary role as antioxidants by destroying free radicals. Its effect was comparable to that of the standard, i.e., alpha tocopherol. At higher concentrations the activity of polyherbal combination was even greater than that of the reference control, alpha tocopherol. Inferring from the results of macrophage activation parameters, it can be said that the extract of Boswellia serrata at different concentrations has the capacity of increasing percentage phagocytosis, carbon clearance and intracellular killing capacity, hence it can be undoubtedly used to modulate our immune system. This is in accordance with the result of Syrovets and Makare [30] who also reported the immunomodulatory activity of Boswellic acid, but involving different assays. This study suggests oral BS extract might be a potential therapeutic strategy for immune related disorders $[33,34]$. Recently also, Beghelli et. al have demonstrated the Antioxidant and immune system regulatory properties of Boswellia serrata extracts but in ex vivo model unlike this study $[35,36]$.

\section{Conclusions}

The promising results of the study support to the fact that the chosen herb, Boswellia serrata, exhibit a significant antioxidant activity as well as immunomodulatory activity in murine model and it shall be equally efficacious for human beings. The significance of investigation is that the study helps in providing novel plant based prophylactic agents that would minimize the usage of chemotherapeutic agents, thereby avoiding undesirable side effects encountered with those agents, without interference in the biochemical processes of normal cells. However, there is need of fully integrated approach for the development of new therapeutics, standardization and validation of known herbal medicines and other related aspects.

\section{Acknowledgements}

The authors are very grateful to Dr. N. Ganesh, Head of the Department of Research, Jawaharlal Nehru Cancer Hospital and Research Center, Bhopal (M.P), for providing experimental facilities, and for his appropriate and constructive suggestions for the present study.

\section{REFERENCES}

[1] S.N Upadhyay. Therapeutic potential of Immunomodulatory agents from plant products. In: SN Upadhyay Ed. 
Immunomodulation, New Delhi, Narosa Publishing House, $149-154,1997$

[2] M. Bertocchi, G. Isani, F. Medici, G. Andreani, I. Oscar, et al.Anti-inflammatory activity of Boswellia serrata extracts: an in vitro study on porcine aortic endothelial cells, Oxid. Med. Cell. Longev. Vo.9, 250-305, 2018.

[3] I C-Zapata, J C-Canche, K F-Martín, Z M -Quintal, J C Torres, J C L-Riegos, Immunomodulatory effects of the methanolic extract from Pouteria campechiana leaves in macrophage functions, Volume 29, Issue 1, Pages 386-399, 2018.

[4] C.Desmarchelier, A.V.Pacciaroni, D.Abate-Daga, J. Coussio, R.R, Gil, G.L.Silva. Antioxidant and free radical scavenging activities of Misodendrum punctulatum, Myzodendrone and Structurally Related Phenols. Phytother. Res, Vol19: 1043 - 1047, 2005.

[5] U.N Mahaja., D.D.Wasule. Sunscreen and anti-oxidant activities of herbal gel formulations. Phoog Mag. Vol4, No.13, 99 - 101, 2008.

[6] S.A.Aherne, J.P.Kerry, N.M. O'Brien. Effects of plant extracts on antioxidant status and oxidant-induced stress in Caco-2 cells. British Journal of Nutrition, Vol 97, 321 - 328, 2007.

[7] U.M.Thatte, S.A.Dahanukar. Rasayana Concept: Clues from immunomodulatory therapy. In: SN Upadhyay Ed. Immunomodulation, Narosa Publishing House, New Delhi. $141-148,1997$.

[8] T.P.A.Devasagayam, K.B.Sainis, Immune system and antioxidants, especially those derived from Indian medicinal plants. Indian Journal of Experimental Biology, Vol40, 639 $-655,2002$.

[9] V.Gayathri, V.V. Asha, A. Subramoniam. Preliminary studies on the immunomodulatory and antioxidant properties of Selaginella species. Indian Journal of Pharmacology. Vol.37, No.6, 381 - 385, 2005.

[10] B.Patwardhan, M. Gautam. Botanical immunodrugs: scope and opportunities. Drug Discov Today. Vol.10, No.7, $495-$ 502,2005 .

[11] A.Singh. Herbal Medicine-Dream Unresolved. Pharmacognosy Reviews. Vol 1, No.2, 375 - 376,2007.

[12] S.K.Kulkarni, Hand Book of Experimental Pharmacology, 3rd edn. Delhi: Vallabh Prakashan,1999.

[13] P. Sharma. In: Charaka Samhita, Chikitsasthana, Chaukhamba Orientalia, Varanasi, Indian Drugs. 2, 1983.

[14] R.A.Mothana, Anti-Inflammatory, Antinociceptive and Antioxidant Activities of the Endemic Soqotraen Boswellia elongata Balf. F. and Jatropha unicostata Balf. F. In Different Experimental Models. Food and Chemical Toxicology, Vol 49, No. 10, 2594-2599, 2011.

[15] M.A.Ayub, M.A Hanif, R.A. Sarfraz,M. Shahid, Biological activity of Boswellia serrata Roxb. oleo gum resin essential oil: effects of extraction by supercritical carbon dioxide and traditional methods, International Journal of Food Properties, Vol.21,No.1, 808-820,2018.

[16] M.Padhi, S. Mahapatra. Boswellia serrata: a review of its traditional uses, phytochemistry and pharmacology, IREBIC,
Vol. 4, No.2, 74-83, 2013.

[17] A.Sharma, A.S.Mann, V.Gajbhiye, M.D.Kharya, Phytochemical Profile of Boswellia serrata: An overview. Pharmacognosy Reviews, Vol 1, No.1, 137 - 142,2007.

[18] M. Z. Siddiqui. Boswellia Serrata, A Potential Antiinflammatory Agent: An Overview, Vol 73, No.3, 255$261,2011$.

[19] Y.Zhang, Z.Ning, C.Lu, S.Zhao, J.Wang, B.Liu, X.Xu, Y.Liu, Triterpenoid resinous metabolites from the genus Boswellia: pharmacological activities and potential species-identifying properties, Chem Cent J, Vol $7,153,2013$.

[20] M.Gupta, P. Rout, L.Misra, P. Gupta, N. Singh, M.Darokar, D. Saikia, S.Singh, R.Bhakuni. Chemical Composition and Bioactivity of Boswellia serrata Essential Oil in Relation to Geographical Variation Roxb. Plant Biosystems, Vol 151, No.4, 623-629, 2016.

[21] K. Bairwa, S.M.Jachak, Nanoparticle formulation of 11-keto- $\hat{I}^{2}$-boswellic acid (KBA):anti-inflammatory activity and in vivo pharmacokinetics, Pharm Biol, Vol 54, No.12, 2909-2916, 2016.

[22] H. Hussain, A. Al-Harrasi, R. Csuk, U. Shamraiz, I.R. Green, I. Ahmed, et al. Therapeutic potential of boswellic acids: a patent review (1990-2015); Expert Opin Ther Pat, Vol 10.1080/1354, 2016.

[23] A. Chaurasia, A. Gharia, Antifungal activity of medicinal plant Boswellia Serrata. Journal of Ultra Chemistry, Vol 13, No.4, 88-90,2017.

[24] A. Notarnicola, G.Maccagnano, L Moretti, V.Pesce, S.Tafuri, A.Fiore, B.Moretti, Methylsulfonylmethane and boswellic acids versus glucosamine sulfate in the treatment of knee arthritis: randomized trial, Int $\mathrm{J}$ Immunopathol Pharmacol, Vol.29, No.1, 140-6, 2017.

[25] N.Pilkhwal, S.Dhaneshwar, An update on pharmacological profile of boswellia serrata, may, Vol 12, No.5, /0000-0001-7646-642x, 2019.

[26] S. Bakhtiari and F. Nematzade, Phenotypic Investigation of the Antimicrobial Effect of Organic and Hydro-Alcoholic Extracts of Boswellia serrata on Oral Microbiota, Vol 4, No.1, 203-211, Jan-2020.

[27] M Gahlot, P Bhatt and J Joshi, Study on Yield of Plant Extracts Using Different Solvents and Methods, Bulletin of Environment, Pharmacology and Life Sciences., Vol 7 [6] May 2018.

[28] P. Italiani, \& D.Boraschi, New insights into tissue macrophages: From their origin to the development of memory. Immune Network, 15(4), 167-176, 2015.

[29] K.C.Navegantes, R. Gomes, P. Pereira, P.G. Czaikoski, C.H.M. Azevedo \& M. Monteiro, Immune modulation of some autoimmune diseases: The critical role of macrophages and neutrophils in the innate and adaptive immunity. Journal of Translational Medicine, 15(36), 328-321., 2017.

[30] P. Agarwal. Determining Glutathione Levels in Plants. Chapter from book Plant Stress Tolerance: Methods and Protocols. pp.273-277, July 2017.

[31] A.K.Gupta, N. Misra, Hepatoprotective Activity of Aqueous 
Ethanolic extract of Chamomile capitula in paracetamol intoxicated albino rats. American Journal of Pharmacology and Toxicology,Vol. 1, No.1, 17-20,2006.

[32] J. Sochor, P. Salas, J. Zehnalek, B. Krska, V.Adam, L.Havel, R.Kizek, An assay for spectrometric determination of antioxidant activity of a biological extract. Lis. Cukrov. Repar, Vol 126, 416-417, 2010.

[33] F.Shah, A.Khan, A.Husain. Phytochemistry and potential therapeutic actions of boswellic acids: a mini-review, Asian Pacific Journal of Tropical Biomedicine, Vol7, No.6, 513-523, June 2017.

[34] A. A. Gomaa, H. S. M. Farghaly, D.A. E Sers, M.M. Farrag
\& N. A Zokeim. Inhibition of adiposity and related metabolic disturbances by polyphenol-rich extract of Boswellia serrata gum through alteration of adipo/cytokine profiles. Inflammopharmacology vol 27, 549-559, 2019.

[35] M. Muhammed, S. Majeed, N. K. Narayanan and K Nagabhushanam, A pilot, randomized, double-blind, placebo- ${ }^{-}$controlled trial to assess the safety and efficacy of a novel Boswellia serrata extract in the management of osteoarthritis of the knee, Vol. 33, 5, 1457-1468..May 2019.

[36] D. Beghelli, G.Isani, P. Roncada, G.Andreani, O.Bistoni, M.Bertocchi, G. Lupidi, A.Alunno. Antioxidant and ex vivo immune system regulatory properties of Boswellia serrata extracts. Oxid Med Cell Longev,Vol 53, 746 8064, 2017. 